Meta

Journal des traducteurs

Translators' Journal

\title{
Translating and Studying Translation: the View from the Agent
}

\section{Daniel Simeoni}

Volume 40, numéro 3, septembre 1995

La traduction, qu'est-ce à dire? Phénoménologies de la traduction

URI : https://id.erudit.org/iderudit/004146ar

DOI : https://doi.org/10.7202/004146ar

Aller au sommaire du numéro

Éditeur(s)

Les Presses de l'Université de Montréal

ISSN

0026-0452 (imprimé)

1492-1421 (numérique)

Découvrir la revue

Citer cet article

Simeoni, D. (1995). Translating and Studying Translation: the View from the Agent. Meta, 40(3), 445-460. https://doi.org/10.7202/004146ar

\section{Résumé de l'article}

La mise à distance objectivante induite par le « regard éloigné » du chercheur ès-sciences humaines nostalgique des sciences naturelles et physiques classiques occulte le rapport nécessairement engagé et distant du chercheur à son objet, tel que ce rapport est inscrit dans l'étude savante des pratiques. La traduction et la traductologie sont deux de ces pratiques qui gagnent à être reconceptualisées de façon cohérente en s'inspirant de travaux sociologiques de type réflexif (Elias, Bourdieu) et de linguistiques structurales phénoménologiques du type " théories des opérations énonciatives ». Ainsi replacé au coeur du dispositif scientifique, le point de vue de l'agent assumé par le chercheur (i) assurerait la validité du projet traductologique, et (ii) tempérerait la fragmentation naturelle de l'interdiscipline en « îlots de connaissance » (Bruner), à l'image de ce qui s'est produit dans les autres sciences humaines.
Ce document est protégé par la loi sur le droit d'auteur. L'utilisation des services d'Érudit (y compris la reproduction) est assujettie à sa politique d'utilisation que vous pouvez consulter en ligne.

https://apropos.erudit.org/fr/usagers/politique-dutilisation/ 


\title{
TRANSLATING AND STUDYING TRANSLATION: THE VIEW FROM THE AGENT
}

\author{
DANIEL SIMEONI \\ Canadian Association of Translation Studies. Canada
}

\begin{abstract}
Résumé
La mise d distance objectivante induite par le wregard éloigné du chercheur essciences humaines nostalgique des sciences naturelles et physiques classiques occulte le rapport nécessairement engagé es distant du chercheur d son objet, tel que ce rapport est inscrit dans l'étude savante des pratiques. La traduction el la traductologie sont deux de c'es pratiques qui gagnent de être reconceptualisées de façon cohérente en s'inspirant de travaux sociologiques de type réflexif (Elias. Bourdieu) et de linguistiques structurales phénoménologiques du type wshéries des opérations énonciatives. Ainsi replacé au caur du dispositif scientifique, le point de vue de l'agent assumé par le chercheur (i) assurerait la validité du projer traductologique. el (ii) tempérerait la fragmentation naturelle de l'interdiscipline en "illots de connaissance" (Bruner), d l'image de c'e qui s'est produit dans les autres sciences humaines.
\end{abstract}

\section{INTRODUCTION}

My interest in this paper is in making sense of translation studies as a particular configuration of human science. Accordingly, the term 'science' will be considered here in the longue durée an age-old tradition of methodical enquiry leading to the development of knowledge. Appropriate senses and their genealogies can be checked out at items $1,2,3$, and 4 of the OED. Sense 5b, of a term "often treated as synonymous with 'Natural and Physical Science" - now dominant in most Western countries and elsewhere only emerged as a restricted 'English' usage in the 1860s (see the W. G. Ward quotation for exact reference).

This will be my main argument: Science being an evolving practice subject to conditions prevailing in the host culture, it follows that studying human-shaped events can be construed as close in nature to the shaping of the events themselves. For example, the practice of studying translation shares a fair number of experiential traits with the activity of translating. This dual involvement, whereby both the "practitioner involved" and the 'involved student of practice' play an authorial role, entails a number of consequences as to the scope and value of the concept of 'validity' in sciences that deal with such events or complexes of events. As a result, analyses of "products" and "processes" can only gain from focussing on the agent of the practice.

This angle is what I call: "the view from the agent" - a prescriptive stance certainly (but no more so than the traditional 'view from afar') yet by far the most accomodating in terms of the variety of approaches it allows on a scale of formalism. Practice indeed may be 'just' described experientially or, alternatively, formalized as if from the agent's viewpoint. Established branches of the human sciences, e.g. linguistics and sociology, have pointed the way independently to such an inclusive epistemology. That the linguists who have been experimenting with the approach posit a 'subject,' whereas their counterparts in sociology construct an 'agent' is hardly a surprise. Nor is this much of a problem for translation studies. Both interpretations of the phenomenological source are relevant 
to the interdiscipline since translations present themselves as socially marked idiolectal products.

In light of these considerations, a reflection on the evolving status of translation studies in the human sciences will be initiated in the last section of the paper.

\section{THE PRACTICE OF STUDYING PRACTICE}

One way to address the issue of scientific differences is to focus on our individual practices. As a rule, we tend to make recourse, individually, to the same conceptual constructs whatever the focus of our study. We specialize in domains and those domains bear the traces of our epistemological preferences, apparently idiosyncratically. At least for the established among us, the style, substantive contributions and conceptual innovations seem inseparably linked. As Clifford Geertz put it, reading Evans-Pritchard's and LevisStrauss's ethnographies: "the way of saying is the what of saying" (1984: 68). Not only are we bound in our capacity to think objects according to their specificity, we also appear quite constrained in the actual act of research. Individual research moves - the way we do fieldwork, collect evidence, write, organize ideas, focus on this or that aspect of what has to be done, etc. - rarely undergo radical changes in relation to so-called 'objects' of research. The reasons for such permanences, of course, are to be found in the source of human-science practices: the scientist as author.

Inner motivations combine with external interests to suppress the knowledge that these seemingly idiosyncratic leanings have institutional roots. Theoretical and methodological preferences, born out of the national state-bound traditions against which professional training takes place, result from complex alchemies of personal experiences. Not reducible to single types, these differentiated 'tastes' can nevertheless be accounted for and assessed, against the "modal habitus" that commonly serve as references in the relevant (national) fields'. Enlarge the picture, however, first across specific fields then transculturally, and it will become apparent that understanding the variation in research practices requires more than focussing to scale. Given the increasing circulation of researchers across countries, and the ever larger numbers of those raised in a socioinstitutional framework while active in another, misunderstandings and other cognitive dissonances are inevitably reinforced ${ }^{2}$. Babel also signalled the disruption of metalanguages.

Some cross-fertilization takes place for sure, inflecting the mood of the universal community of scholars, but how this operates remains elusive. The regularities observed by polysystemists in the dissemination of models do not necessarily apply to the finer structural transmission of individual styles of thinking, of which comparatively scarce is known. Transfer of knowledge ways may not be so different after all from creative thinking, following analogical models of development rather than linear, discontinuous processes ${ }^{3}$. Further, genuine exchanges are gravely hampered by the monolingualism of those born and raised in the economically dominant regions of the day. Focussing on the special case of the 'disciplines,' the image that comes to mind then is that of a vast expanse of academic knowledge, an ocean of sorts, on which flotillas of scholars sail without compass, unaware and to some extent unmindful, of the positions and pavilions of their fellow-travellers.

Such seemingly erratic diversity in self-contained individual practices has not prevented the scientific community to extol the merits of objectivity as pure and secure "detachment" - a golden rule in knowledge development - whether the object under scrutiny formed part of the physical, natural. social (Elias 1956: 233 sq.) and, I would add, imaginative, worlds. This persisting consensus is surprising, at least as regards the 
sphere of the social sciences and the humanities - an aggregate of fields and sub-fields that distinguishes itself by virtue of its human anchoring, typified by the close conjunction of observer and observed in the very act of research. Comparatively little emphasis has been laid on the researcher to heed more actual conditions of practice.

For there is a demonstrable link between (i) the purely detached scholarly stance of objectivation or, in Bourdieu's words (1990) expanding on Austin's remark (1962), "the scholastic point of view" that is inseparably substantial, conceptual, argumentative, stylistic and, literally, embodied in the author's stance, and (ii) the "sealing in" of the more established disciplines ${ }^{4}$. Such a neglect of the actual conditions of practice has taken its toll, resulting in the disciplines themselves becoming fragmented into islands of knowledge - "each with its own organizational identity, its own theoretical apparatus, and often its own journals" (Bruner 1990: ix), making up specialties that "sell themselves in their own thetoric and within their own parishes of authorities" (id.). Instead of taking our clues from an ideology of research all equipped with "norms and considerations" coming straight out of "older, more established disciplines" (Gile 1995), perhaps we would do better to reflect on what the same critic, a psychologist with impeccable references, recently wrote on the subject:

...if we take the object of psychology (as of any intellectual enterprise) to be the achievement of understanding, why is it necessary under all conditions for us to understand in advance of the phenomena to be observed - which is all that prediction is? Are not plausible interpretations preferable to causal explanations, particularly when the achievement of a causal explanation forces us to artificialize what we are studying to a point almost beyond recognition as representative of human life? (Bruner 1990: xiii)

The argument for a practice-oriented scientific eye bears on the two orders of representation of the human sciences: the object under study (how we deal with the human dimension in our work), and the meta-level of theoretical discourse (what part the human dimension plays in the explanatory construction of understanding). Social facts as lived in and the study of social facts, the psyche-as-experienced and psychology, language as used and linguistics, translation as practised and the scientific study of translation, all these fields of knowledge share more than common root words. Even at a more common sense level, the twin practices just listed do not distinguish themselves readily. Thus. practitioners are eager for guidance, from peers rather than from theoreticians maybe, but bona fide guidance all the same. Furthermore, we cannot vouch that we are always aware of all the choices we make, either as practitioners of the trade or as students of our own practices, or for that matter of others'. In other words, practical performance is no more a random process than theoretical rationality is an a-historical universal, either ready-made for detached inspection or, transcendantally given. Except in time spent then. the difference need not be so clear-cut and principled between (i) practical, involved reflection on one's own practice. which is what every field worker does as a matter of course and (ii), 'scientifically detached' reflection on the outcome or, more directly, on the practice of other people's work. which is what theorists invest their energy into. A good case can be built then, that the difference between the two orders of practice - and their representations - should be minimized, not emphasized by those concerned. All too often, the tendency is to forget that theoretical elaboration takes as its starting point already "a "concrete' model of knowledge, making sense of immediate experience" (Houle 1995). Or, as F. Dubet (1994: 90 ) notes. "les raisonnements des sociologues ne sont pas si radicalement coupés des théories spontanées des acteurs que le postulent les conceptions les plus dures de la rupture [épistémologique]." It will simply not do today to conjure up the magic of epistemic objectivation to distinguish between the two. 
In an article published almost forty years ago, Norbert Elias analyzed precisely the dynamic balancing of involvement and detachment "as tools of thinking." In the human sciences, no work, he says, is the outcome of a completely detached outlook:

... while one need not know. in order to understand the structure of molecules, what it feels like to be one of its atoms, in order to understand the functioning of human groups one needs to know, as it were, from inside how human beings experience their own and other groups. and one cannot know without active participation and involvement. (1956: 237, my emphasis)

It is precisely this component of "participation and involvement" which I would like to relocate center stage since, perhaps owing to

the ascendancy gained, over the centuries. by a manner or style of thinking which has proved highly adequate and successful in men's dealings with physical events. but which is not always equally appropriate if used in their dealings with others (p. 238, my emphasis).

this component seems to be increasingly ignored today. The aim is not to discredit detached stances per se (they have proved their usefulness for the purposes for which they were designed) but to suggest that they are secondary, i.e. peripheral in a sociogenetic sense by comparison with the more involved. i.e. overtly phenomenological postures and also, less elaborate, less true-to-their-objects — in other words less "valid" — than those postures which, having conquered their position of detachment against the conventions, take good heed of the inevitable involvement of the researcher in the act of research.

Specifically. I will contend that, short of taking the vien' of the translator in the act of translating as a solid reference point, any approach (and even more so, any theory) of translation or cultural transfer will run the risk of becoming estranged from its object. This is clearly not enough. The relationship between the object thus defined - i.e. the view from local practice - and the epistemic subject must also be taken care of, but it certainly is a prerequisite. Similarly, without taking the vien' (or "position"5) of the translation scholar in the act of research as a reference point, one is at risk of losing sense of the most revealing aspects of his/her work. This is not relativizing for the sake of it. In fact, it is just the opposite. This principled stance is one way of building into the field of translation studies a minimal condition for shared approaches to translating. The specificity of the field of translation sludies is such, its constitutive object so split up, that it is inherently prone to fragmentation, more visibly so at any rate than any other distinctive branch in the more established disciplines. As empirical work develops, it would be useful to keep some kind of open forum to exchange our views reflexively on the subject, lest "translation studies" be inexorably led to dissolving itself, naturally, into its composite currents (for a candid view of what is at stake, see Robyns 1992: 225). I will return to this in the third section.

To summarize: The foregoing remarks, swaying somewhat between the genericity of the human sciences and the specificity of translation studies, seem to me relevant to all fields of academic knowledge development dealing with human agency - history, sociology, anthropology, psychology, philosophy, literary or cultural studies, and so forth. A science of human behaviour that refuses on principle to foreground the view from the human agent will be perceived by a substantial share of theoreticians, and certainly by a majority of practitioners, as a 'monster,' a machine set up for releasing and sublimating unacknowledged drives for control and powert. The judgement may seem unfair and I would not want it to be taken polemically; for the proponents of seemingly detached, deagentized systemic views may not have had much choice in pushing them, given who they were. their family history, where they were educated, who trained them and the state 
of the field(s) in which they were active at crucial times in their scholarly lives - not to mention more personal group memberships. Our sincerity as individual researchers is not at issue here. Tangible reasons abound why we may prefer to ignore or hush the importance of human "agency" in our daily work. Also, the more insulated one's scholarly practice, the safer his/her protection from doubt. But that need for protection, those motivations and those choices can, and ought to be brought to light, for example by means of a concept like that of illusio, and its collusio correlate (Bourdieu 1977; see also 1980: 67; 1993: 94), otherwise the risk is real of seeing the theoretical enterprise exhaust itself in spurious attempts at building a science of human practice (e.g. translation) on shaky foundations. If anything is to be learned from the history of older. more established disciplines, it is that the epistemological ground on which they once thrived is far from safe today?.

\section{THE VIEW FROM THE AGENT IN THE LANGUAGE SCIENCES:}

\section{LINGUISTICS AND TRANSLATION STUDIES}

Speaking in French at the Universite François Rabelais in Tours in 1983, John Lyons echoed a view he had already developed a year earlier when he coined the phrase "post-saussurean phenomenological structuralism." He was referring 10 , and at the same time was trying to distinguish his own training-induced preferences from, a peculiar brand of continental linguistics inspired by Emile Benveniste's work. None of the terms making up the composite denomination had been used before or, for that matter, have ever been used since, by those directly involved. The 'authorized' expression was, and remains: linguistique de l'énonciation. Lyons may have been killing two birds with one stone; (i) he provided an apt translation for a concept notoriously averse to 'transfer' in the English-speaking world, making it accessible and therefore legitimate outside its original sphere and. conspicuously, (ii) he may have been reaching out to 'the other side' giving them clues as to how their views and the tradition he himself represented could begin to be articulated, thus creating the conditions for a theoretical dialogue between two ideologies of science that were, and remain, poles apart. What he was implying went more or less along these lines: You phenomenologists are clearly more preoccupied with the theoretical status of the speaking subject than we analyticists are, but you remain goodfaith structuralists. On this score at least, we can understand one another. Let's agree to differ then but since we are all trying to make sense of language relations, why not compare your views of what a "subjective" structure is, with our belief in the "objective" order of language (langue)"?

Sadly, such a programmed exchange of views remains as distant today as it was 12 years ago. No one among the French followers of Benveniste or (for another constellation of continental references) of Bühler. has picked up the gauntlet. The two sides - linguists of the continent and those in England (and beyond that, to a large extent, those in the English-speaking world, including Canada) - are facing off today, just as they did in the past. When compatible findings develop, they tend to be ignored - they do not exist, proving Bruner's point about the exclusionary "parishes of authorities" squaring out "psychology`s patchquilt whole." Patchquilts, then, are the rule in 'the disciplines.' But how are we to interpret such a divide in the linguistic field, where people do not even have the lame excuse of not being proficient in a related language? Consider the spirit of openness with which Lyons gave his speech: The interpretation I offer, he said at one point, "nous permet $|\ldots|$ de rapprocher les idées de Benveniste de celles qui appartiennent à d'autres 'écoles' linguistiques d'outre-mer. Cela me semble d'autant plus important que ce colloque international vise à propager les enseignements de Benveniste sur la linguis- 
tique générale au-delà de leurs frontières actuelles" (1984: 136). And again: "Une telle analyse s'impose $|\ldots|$ si nous ne voulons pas nous contenter de rester ancrés pour toujours chacun dans notre petit bras de mer" (137). The potential benefits of his strategy were immense for the development of knowledge. Not only did the term "phenomenological structuralism" loosen Saussure's constraining formula: more crucially, it created a theoretical balance between "structure" and "subject," i.e. between the "logical form" dug out by the detached outsider and the involved perceptions of the speaking subject or, in socioanthropological terms, between "structure" and "agency." hetween the tyranny of psychosocial determinations and the hemmed in creativity of human consciousness - a balance Lyons suggested in the end should be struck for the benefit of all: "Il faut savoir tenir la balance égale entre ceux qui cherchent à universaliser la subjectivité et ceux qui veulent objectiver la signification" (139). What a lost opportunity!

For in "phenomenological linguistics" as it has existed for some 25 years in France and to some extent in Europe, the scientific character of the method is not to be doubted; simply, the focus is different, in keeping with its new object. Emphasis is no longer on the logical organization of the faculty or "mental organ" of language (Chomsky). nor on measurable and classifiable speech variation according to severely controlled social contexts (Labov), nor even simply on the dependence of form upon the function of utterances (functionalisms) nor again on the structural interplay of symbolic representation, mostly analogical, within and across individual languages (cognitive linguistics). Rather, the focus of analysis is brought to bear directly on "l activite langagicere en tant qu'elle est façonnée par la faculté de langage." One consequence of this open definition is that it gives priority to the study of extended deixis or modality", or to take up Senko Maynard's brilliant formulation. "discourse modality" (1995). According to this view, the inscription of the speaking subject is directly traceable in his/her utterances, formalizable as if from his/her point of view'. instead of the inner structure being accessed indirectly by external observation, segmentation. classification and articulation of writtenly biased (Linell 1982) sentences, phrases, speech parts, morphemes and phonemes, all from the vantage point of a detached, omniscient observer. I can only observe that historically, this approach has been second, not (o) say that it has consistently been denied 'scientific' status, in the English-speaking world".

The implications of such a departure from 'objective' formalism are not trivial. To begin with, the conflict between philosophical approaches and the natural-science model of methodical inquiry, always ready to erupt in language matters as in any other human science, loses ground. With the linguistic production of utterances (inonciation) conceptualized from the agent's standpoint, other possible pathways open up for research: linguistic facts meaningful to their authors can simply be described. compared or, if need be, counted. tabled or scatter-plotted. Empirical work can begin to be conducted across the notorious quantitative/qualitative divide. For what scientific subjectivation does is, to place strong constraints on the manipulations of quantitative empiricism, precluding most risks of "mistaking the things of logic for the logic of things." Hesitations, pauses, etc. can be shown to be signifying markers following a non-random distribution in the flow of speech (Simeoni and Fall 1992). All manners of regulations can be found, in other words. in domains that are simply out of bounds within the narrower paradigm of the scientific method.' Those domains, while they may be of great significance for understanding the object, otherwise remain excluded, out of methodological blind faith: "The exclusive and semingly final character of many current statements about the scientific method finds expression in the strange idea that problems which do not lend themselves to investigations by means of a method modelled on that of the physical sciences are of no concern of people engaged in scientific research" (Flias 19.56: 240). Such a phenomenological lin- 
guistics is a far cry from the versions praised or, more usually, criticized in the past by translation scholars (see e.g. Nida 1946, 1964, 1975; Catford 1965; Mounin 1963; Qian $\mathrm{Hu}$ 1992-1994). I can only attest here that students are susceptible to its potential both in linguistic and translation theory courses. Which brings us now to the hypothesis of the validity of phenomenological approaches for translation studies.

\section{Translation studies: a phenomenologically structuralist reading}

A science dealing with the transfer of human agencies in hypothesized systemic wholes. translation studies precipitate all the traits of other human sciences.

A phenomenological stance, qualified by rejection of generalized relativism, was conceptualized in sociology by Norbert Elias as early as 1956. That there is more to it than a matter of who is right or wrong ("objective" truth versus falsehood) is corroborated in an interview with two Dutch social scientists (A. J. Heerma van Voss and A. van Stolk) in which Elias, then aged 90 , recalled the hostile reception to his ideas during a seminar he gave regularly in England. His views on 'what is sociology' and on the human sciences in general, conflicted with the local modal habitus abided by his younger British colleagues:

One of these lectures was about personal pronouns. In it I said that as a sociologist one had to see things from the I-perspective, from the he/she perspective, from the we-perspective and from the perspective of the third-person plural - and all at the same time. I think that is a very good idea, but it was not at all well received $[. . . \mid$ The young people in the department probably regarded my innovative ideas as continental whimsy - though they were never tactless about it. But they did oppose me violently: hardly had I finished speaking than the battle started, and the whole seminar of my colleagues split into two hostile groups. (1994: 66-67)

I would hypothesize a direct relation: the more established the discipline, the stronger the rejection of "other" stances. Elias's anecdotal evidence suggests that, despite the fact that he was invited unfailingly to participate in the seminar, the historically constructed modal habitus of his fellow-sociologists had made them impervious to an approach that broke the charm of the neat divide between "subjects" and "objects" 10 .

Newer disciplines, less concerned with formalism, do not have this difficulty (although they may be shy of distancing themselves too much from the authorized practices of older disciplines in the same "national" field). From within the field of English Studies, L. Marcus (1995) analyzes the impact of autobiography as a legitimate mode of writing criticism in 'cultural studies.' Following Andre Gorz's example in The Traitor. she writes, more critics in the 1990s have been formulating their ideas unabashedly from the ' $I$ '-perspective, using subjective ' $I$ '-markers instead of the 'objective' passive or even "we-saying, [thus] revealing the anxiety of the times about 'speaking for others." She seems sympathetic to these authorial strategies. suggesting that the trend is not to disappear easily from authorized practices of criticism:

It goes along with an increasing suspicion of the 'impersonality' and 'objectivity' of theoretical discourse viewed as concealing the first person and denying the 'situatedness' of the person theorizing.

Writing in 1995 and in the context of a highly feminist-influenced field, it is significant that many of the authors she quotes initiating this trend are continental Europeans: $A$. Gorz, P. Lejeune, A. Lyotard, L. Irigaray. In contrast, none of the non-Europeans quoted are males.

But, perhaps the main reason why translation scholars should heed J. Lyons's advice, lies in a fact rarely mentioned these days: Translating, most evidently, is a 'lin- 
guistic' practice, in the sense of being a practice anchored deep in the materiality of language(s). It makes sense therefore to define such a phenomenological programme, adjusted to the case of translation studies, as focussing on the act of translating (in short: 'translating') insofar as it is fashioned by the faculty of translating, i.e. the inherently social ability to translate. I insist on the social dimension only because it seems to have been somewhat neglected lately in empirical research on 'processes,' following the inherited "manner or style of thinking" of cognitive psychology. Emphasizing the social dimension also has another advantage: In focussing on the phenomenological structuralists" reading of language structures, my formulation has fluctuated between two terms: 'subject' (as in sujet-enonciateur) and 'agent.' As in all matters of terminology, variation is meaningful. Rather than attempt a demonstration. I will simply say that the 'agent' is the 'subject,' but socialized. To speak of a translating agent, therefore, suggests that the reference is a "voice," or a pen (more likely a computer Ioday), inextricably linked to networks of other social agents. Besides, unlike the 'subject,' the 'agent' may be conceived of as instituted.

Conceptualizing translation studies in a way that makes sense of the current diversity of the field may be facilitated then by focussing on the translating agent, and on the epistemic "subject" that is trying to make sense of him/her. The latter is also an "agent." this time the scholarly agent, struggling to appear detached, yet just as involved as his/her "object" in the interplay of social forces in society. Among the most visible regulated effects to be anticipated of the trend towards the scienticization of translation studies is a loss of unicity of the epistemic subject (see Knorr-Cetina 1995) resulting in papers being submitted by collectives of authors, hierarchically arranged. This trend has just begun, on a modest yet significant scale, in Meta. At the other end, the "literary" pole of translation studies can be predicted to remain artisan-styled, mindful, even jealous of the creativity of its participants. Cases of 'plagiarism' too, in the context of the dominant culture (Scollon 1995) will be easier to deal with on the literary pole. A narrower scientific reading would probably result in the protection going to the copyright-holder. It is clear on all these counts that the traditional notion of 'subject' has to be refashioned. That the sociological notion of 'agent' is more pliable to the realities of the field is also borne out by the very tangible manifestations of the translating agent, as can be seen with the massive upsurge of translating pools and agencies on the market in the last twenty years.

Making sense of translation from the agent's viewpoint would facilitate readmission of linguistics into the field of translation studies. As long as the - almost mythical - stance of 'detachment' is taken for granted by the participants, only one configuration is likely: fragmentation within, and partitioning between. fields. Object-centeredness polarizes. On the other hand, an "I"-centered linguistics will naturally meet the terms of equally "subject"-centered sciences, e.g. sociology or, for that matter, translation studies". Suffice it to say that the focus of such a linguistics in a phenomenologically structuralist perspective is the modal component of the clause, i.e. everything that signals the author/translator's involvement in the formulation (énoncé ), as opposed to its propositional content, or the part logically processed. Interestingly, the distinction between (i) focus on extended modality or hyper-syntax and (ii) emphasis on code or syntax overlaps with the preferences laid open by J. Lyons at Tours and incorporated in the modal habitus of (i) continental linguists and phenomenologists, (ii) Anglo-saxon linguists and analytic philosophers. A significant part of the elusive object of translation studies on this basis seems to be provided by all that translation machines will, predictably, always flunk (BarHillel 1960). Machine translation has been, and will remain, notoriously deficient in dealing with the modal component of enonciation, for principled reasons. A large part of the difficulty of translating can thus be theorized as a 'discriminating task': sifting the 
idiosyncratic character of the utterance out of the instituted componentiality of the translating agent's production.

\section{WHAT STATUS FOR TRANSLATION STUDIES IN THE HUMAN SCIENCES?}

The acknowledged ambition of translation studies to become an autonomous discipline invites revisiting the terms of its conceptualization. Translation studies was doomed from the start to confront the issue of where it stands on the "theory spectrum" (GaddisRose 1994). Dealing with at least two languages, i.e. two cultures, its object has been constitutively split along its two main components of interest, even though the divide metaphor here is probably too clear-cut. We would keep closer to experienced practice if we referred to the multiple personalities (i) of the translating agent, (ii) of the translation scholar.

The translating agent straddles the borderline between cultures. Although various pressures associated with practice force him/her to "stay home" - on the target side $s /$ he cannot afford to ignore the source-field a long time without being at risk. Less noted, curiously, has been the fact that being involved in translation studies also requires choosing between competing approaches - a situation that reproduces the multiple personality of the translator, this time in the translation scholar's mind. This is particularly evident when his/her preferences are negated by the environment within which s/he operates (see e.g. note 2 on Friedmann. Spitzer and Bettelheim and the disciplines or, for that matter, $\mathrm{N}$. Elias's reflections on England. Of his 40-year stay in that country, he was able to say: "it was a very gradual, sliding disengagement." [1994: 62]).

Certainly, all human sciences, at some stage in their development, have had to confront the issue of which criteria to use to determine the validity (scientificity) of the research going on in their behalf. I leave aside the issue of the historicity of the concept of validity, only to recall that it is no more a-historical than science itself is. We might begin by noting that nothing in the ideal word of scholarship, in principle, would seem to stop one from choosing freely among the competing approaches available, either alternatively or, better in the case of translation studies, mixing them. For those national contexts I know however ${ }^{12}$, the evidence is that, across disciplines, only two such aggregates of approaches stand out today, ever consistently, as was already the case at the turn of the XIXth century - which should make us suspicious of the universal image in which each aggregate presents itself. These approaches are located somewhere on a line defining the two age-old human-science paradigms of the arts and sciences in Western culture. I have already referred to them as (i) the 'philosophical approach' and, (ii) natural-science modelling' (henceforth NSM).

There is always a possibility of course, suggested earlier. to paddle away and stay the course. But the case of the interdiscipline is different. For one thing, the scholar who keeps abreast of developments at home exclusively, only does (at most) half the work. Secondly, it would be a sad comment. I think, on the notion of knowledge development, if only those works originating in economically dominant regions were deemed licit. Examples can certainly be found of scholarship borrowing from several traditions. Yet, such efforts are far from being the rule. The pressures are enormous on students from other countries (or national entities) which do not control the certification of expertise, to conform to styles of thinking that are alien to them. Symbolic violence, because it is not even recognized most of the time by those who wield it, is one of the most damaging factors to genuine knowledge development. This, I believe, is a matter worth thinking about: if we agree that translation is an interdiscipline, how satisfying is it that the dominant, modal model( $s)$ in relation to which our work is oriented, do(es) not borrow(s), if not 
from all sides, at least from each of the relevant sides "in contact"? True to the predictions of Polysystem theory, it would seem that only target systems count. in translation theory as well as in translation tout court.

What we have here of course is the 'two cultures' debate coming back on us with a vengeance. Only this time it reaches us in a trans-national champ de connaissances whose identity is being called into question. The sciences humaines, divided as they are between the humanities and the social sciences, have been tearing apart. As macrochanges of policy come to bear on the nitty-gritty of our work. pressures are stronger for researchers to move towards, and swear allegiance to the strictest of NSM. Projects and programmes submitted to funding agencies routinely include a token quantitative (statistical) section, in cases where, only ten years ago, this would have been unthinkable. Conference organizers multiply calls to the same effect. sometimes promising miracles simply by conjuring up the latest devices from behaviourist cognitive logic.

\section{Extra-territoriality of the interdiscipline}

Translation scholars, while participating in an extraterritorial field, have in fact persistently borrowed their models and inspiration from their more established counterparts in the disciplines:

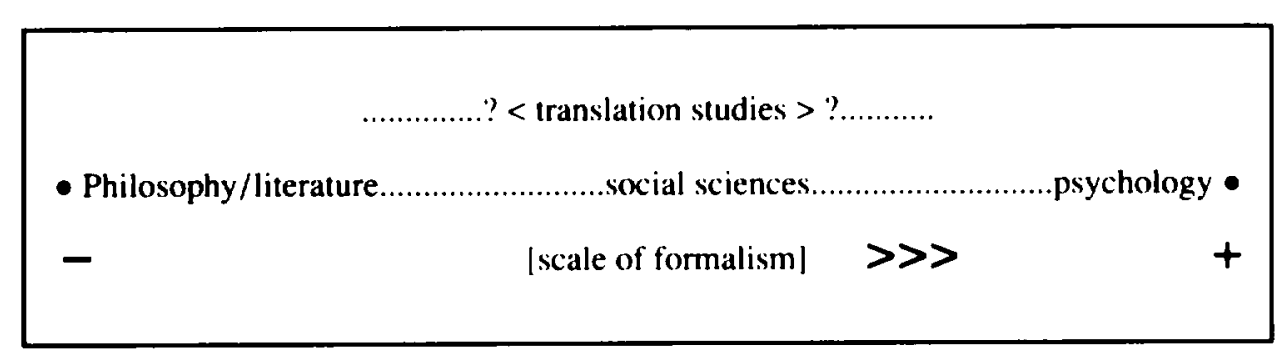

\section{Figure I}

A few quick comments are in order:

- Figure 1 is not prescriptive. I am proposing it as just one convenient way of representing the tension inherent in translation studies and other social sciences. Categories laid out above are considered in relation to the dominant model of harder sciences - 'classical' physics and chemistry - on the right-hand side of the box (right of the ' + ' sign). I am not fetishizing this representation. Indeed, I can easily think of other diagrams in which literature would be 'on top.' or history, etc. Similarly, the directionality of the left-to-right scale could be inverted, taking 'non formalism' this time as the rule.

- The diagram represents a spectrum of possibilities, with overlapping areas. Indeed, it is best visualized as a space, bi- or even better. tri-dimensional, in constant evolution/relocation under the combined influence of involved agents. This is all the sense of interdisciplinarity.

- I am referring to the left-hand pole of the axis (lowards the '-' sign) as the space of "philosophy/literature". It seems to me that the too casual acknowledgement this area of expertise gets by labelling it simply "speculative" and "meditative" (Gile 1995) is undeserved, as these terms give in to the worst prejudices; what they connote, even in French today, is irrationality and (non-scientific) subjectivity. Similarly, I have preferred to historically label the right-hand pole "psychology" rather than "NSM," since. across national-state fields, the area of knowledge thus delimited is larger and includes 
researchers active in many sub-fields situated "farther left" than the narrowly defined NSM-styled psychology of the Cyril Burt and American Psychological Association types. Strict NSM therefore is to be viewed as occupying the right end of the spectrum, an extreme position indeed, drawing its methodological inspiration from the successes of biology and perhaps even chemistry and physics and, it must be said, unmindful so far of the criticisms levelled at it by those who claim that applying NSModelling to social agents is epistemologically dubious 13 .

- So far, translation studies, as an interdiscipline, have well exceeded the scope of the basic disciplines. Despite the fact that in each disciplinary field (philosophy, sociology, psychology) some have argued that theirs is the paradigmatic human science, this ambition, predictably, has not been recognized across fields. Indeed, in sheer variety of participants and diversity of practices, the scope is probably widest in translation studies. This, with the realities of their uncertain status, justifies placing translation studies' peculiar "patchwork quilt" on a separate axis, or plane, parallel to that of the more established disciplines.

- The recent advocacy of those who would restrict the scope of the field to the right-hand side of the spectrum or, at the very least, displace its center to that end, puts it particularly at risk of breaking down again in so many sub-areas. For the left-hand side will not disappear - it never has. It will rather secede. This eventually would result in fusing the higher and lower tiers into one single plane, introducing in translation studies, as it became specialized, the "parishes" and divisions plaguing the other human sciences. The Anglo-saxon world seems particularly exposed, because of the particular history of the human sciences in that geographical area ${ }^{14}$. Distinct histories have given shape to distinct practices that the regular compartmentalization of work prevents seeing. The main federal funding agency in Canada thus mirrors in its very denomination, an inherited division between the two historically dominant cultural models. In SSHRCC/CRSHC, the social sciences and the humanities of some are the sciences humaines of the others. A dual Conseil de Recherches en Sciences Sociales et Humanités/Council of Research in Human Science, although not an 'implausible' option by any means, would obliterate its source in distinct Europan cultural histories. So far, this contrastive heritage has not been negated.

- Semiotics once provided a persuasive all-encompassing model subsuming the diversity of translation studies. No doubt in reaction against the then prevalent human-science paradigms of Freudianism and Marxism, many semioticians tended to downplay the psychosocial dimensions of culture. This resulted in a typically systemic shift: the two 'excluded' sub-systems reappeared in different shapes, somewhat less bounded than they used to be, in the so-called 'cultural studies' - now dominant in the Humanities in North America and in England, on the left side of the spectrum. This in turn left the right pole free for the proponents of a reinforced NSM-model ' ++ ' to settle in, recreating, instead of an orderly semiotic structure for the human sciences, yesterday's traditional two-culture motif. This time: cultural studies vs NSM- ++15 .

The theory spectrum has thus taken a new shape. where two scientific cultures are becoming polarized again. with the social sciences generally (as well as translation studies in particular as social interdiscipline) hard pressed to choose between the two poles: 


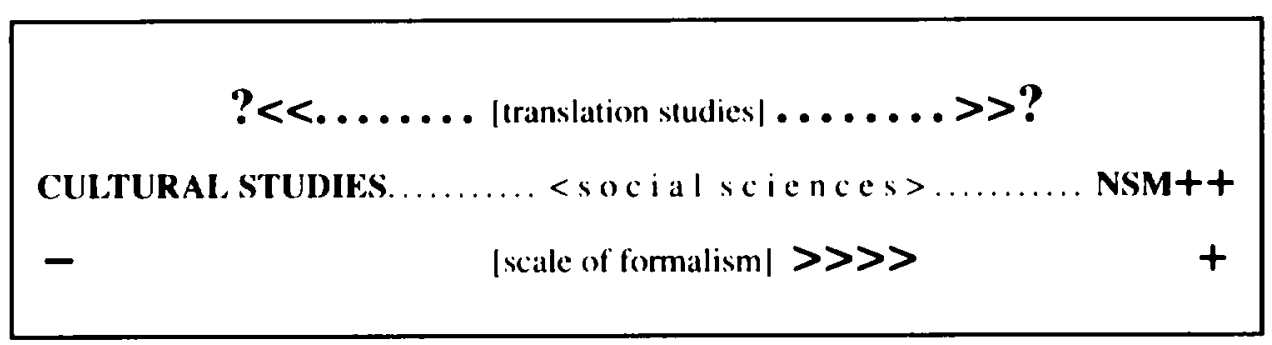

\section{Figure 2}

This new interdisciplinary landscape is fully operational. It has already infiltrated the minds of the profession, creating a rift between those who accept it de faclo. pulling at it in one or the other direction, and those who do not. Or cannot envision it consciously. Between those firmly established and others, aspiring to their interpretations and models of understanding acquiring higher status. Because the landscape is transnational (although not universal!) and dynamic. I find that it contributes to a better understanding of each and every participant's moves, down to the routine work of reviewing new books. The established in the established disciplines will thus tend to oppose the new arrivals" substitution of "cultural studies" for the more traditional "philosophical" approaches. For example: In a recent critique published in the Revue française de sociologie. Francois Chazel (1993) disagreed with W. Lepenies's conceptual account (1985) of the advent of sociology as a discipline that had to carve a niche midway "between literary criticism and natural science," a connection which he considered "exaggerated and largely imaginary." taking it to be an "unconventional analysis of the history of sociology" (instead of agreeing to a conceptual history recast in the mould of the human sciences in the 1980s). Reading such reviews (in which the established reject the newcomer's interpretation) while keeping in mind the above spatial representation of the field makes very clear that the participants' stakes are more involved than the official objectivist story would have us believe. Similarly, today's unstable status of translation studies as a human science, together with the determined attempts by some within its ranks to mould it into a more "scientific" discipline, will remind the historically aware of precedents; the way in which for example the first generation of French sociologists after the second World War was torn between two polarized worlds: on the one hand: the world of intellectual involvement symbolized hy Sartre; on the other. the world of expertise and statistics represented by the well-endowed state institutions of INSII: and INED. As recalled by Johan Heilbron in a recent study, according to the official story built up at the time by those with an interest in it. for the benefit of their foreign colleagues: "La nouvelle sociologie française était "moderne", "empirique" et enfin adibérée» de l'emprise de la philosophie. La sociologie "générale» (sous-entendu: «spéculative») n`était plus représentative" (Heilbron 1991: 365). Plus sa change'....

\section{CONCLUISION}

The tension within interdisciplinary translation studies is a reflection of the tension in the social sciences in an age of academic reconfiguration. It should not come as a surprise that this tension bears most directly on the third, intermediate culture of science, borrowing both from the literary tradition and from the scientific models of nature according $10 \mathrm{~W}$. Lepenies (1985). In-depth analysis of the reasons for this reconfiguration 
lies outside the scope of this paper. I have tried to argue that a strategic response by those affected - those who do not easily resign themselves to the prospect of a clear-cut divide between cultural studies and NSModelling and the ensuing sub-fragmentation and absorption of the field - may lie in reconceptualizing the interdiscipline itself around the principle that I have called the view from the agent. The consistency of the field would then be iconic of the consistency previously noted in the language choices of the author/translator.

\section{Notes}

I. I have made use, on several occasions (1992, 1993a and b), of this reading system, directly inspired by Bourdieu's model (for references, see e.g. 1987: 256; 199.3: 1994: 99-145) to conceptualize the 'translating habilus.'

2. To give but a few examples: The German sociologist Friedrich Friedmann, who fled Nazi Germany for the US, participated in ground-breaking fieldwork in laly after the second World War. giving that country its decisive impulse on the way to building a sociological tradition. Returning to Germany in 1959 to end his academic career in Munich, he taught his subject of expertise: sociology. During his stay at the University of Arkansas however, he had been given the responsibility of philosophy courses (Rammstedt 1995). Another example is the literary critic, Leo Spitzer, who spent considerable time in his articles while he was in Princeton, trying to convince his readers and students that his method for analyzing literary works, an extension of the principle of the "philosophical circle" (Dilthey's Zirkel im Verstithen), was anything but "arbitrary' ( see e. g. Freccero) 1988: Spituer 1988: 37). For his part. Bruno Bettelheim, as became clear to all with the publication of his Reflections. Fresad and the Seral in 1982, never really adjusted to a life lived out as an exile despile his successful career at the Orthogenic scheol of (hicago. These clearly are specific cases of cultural incomprehension, not to the interpreted generically. Fundamentally. the relation is far from clear between these and countless ordinary failures at communication across fields of specialty. "Pourquoi le dialogue entre économistes et sociologues est-il difficile? Pourquoi risque-t-il d'impliquer tant de malentendus: Sans doute parce que la rencontre entre deux disciplines est la rencontre entre deux histoires diftérentes, donc deux cultures differentes" (Bourdieu 1984: 23). Although the relation between the two types of incomprehension is an object of study in itself. crossing borders can only exacerbate the feeling of estrangement.

3. An interesting attempt to answer this question has been that of A. I. Miller (1986), trying to delve empirically into the hands-on intuitive dimension, particularly the mental imagery of creative thinking, that gave way 10 the innovative works of Poincare, Einstein. Bolzmann. Bohr and Heisenberg in 20th-century physics. Building plausible scenarios on the basis of available archival data as well as primary and secondary sources, Miller was able to propose a model of scientific development parallel with that of genetic epistemology, in which the propositional and literal encoding of novel 'images' of knowledge is mitigated, however. by the inclusion of classical Gestalt psychological figures and, above all, less importance is given to "crucial and critucal discontinuities" in the creative process.

4. The exact measure of the toll paid by the dixiplones under such "sealing in" circumstances was assessed by Norber Elias with special reference to sociology: "In the tate twentieth century sociological research and teaching have become professionalized and bureaucratized to a high degree, as happens with established disciplines, very often along the lines of models bortowed from the scientific and philosophical establishment $|. .$.$| But the professionalifation and bureaucratization of scriology, the praclical advantages of which$ are undisputed - and are indeed unavoidable given the present conditions under which the human sciences operate at universities - have also brought with them a certain narrowing of sociology's perspective, a cerlain impoverishment of its imagination and sensibility" (1994: 131). It should he noted that Elias's own itinerary as scholar-in-exile kepe him naturally alen to the national boundaries of scientific moxds. Whereas others would have opted for one OR the other, he refers in the same breath to "the scientific AND philosophical establishment." Only an involved observer spending his scholarly life equally marginalied in England and in continental Europe could have had recourse to such a formulation without secing in it a contradiction in terms.

5. Mossop (CATS 1995) calls this view a "stance," a particularly apt formulation as it preserves the physical. i.t' bxclily component of Bourdieu's concept of "position." Assuming for my part 'the view from the agent." I have tended to interpret this concept as "posture" (Simeoni 1995).

6. Max Weter's insights on rational sublimation are worth recalling in this respect: "...the rationality, in the sense of logical or teleological "consistency.' of an intellectual-theoretical or practical-ethical altitude has and always has had power over man, however limited and unstable this power is and always has been in the face of other forces of historical life" (1946: 324). It is always the case that dedication to research is of a quasi-erotic nature: the question is. how can this sublimation the brought to consciousness in the act of research itself? Which is the only way perhaps 10 make sense of this peculiar activity that consumes lives. 
Such awareness, it seems to me, is particularly important in the case of translation studies, as the risk is inherent in them to displace the drive for power from the individual level to that of the cultural identity of the researcher. This drift manifests itself sometimes quite crudely in axiological terms: "my" culture is more 'precise." or 'rational. "or again. more 'soul-searching' than theirs...

7. I do not have in mind here the "polysystem' model, which certainly allows for various degrees of "agencyfecus." On a scale of opennes, there are certainly far more closed systems. What is common for example to Chomsky's work as a linguist and at social critic, despite his repeated statements that the connection between the two is only 'tenuous, lies precisely in that kind of protection from the messiness of agency, so that a tight link can be hypothesised hetween (a) (homsky's systemic view of sectal life in which everything is "seen" and exposed as if from inl oussider's vantage point, and (b) his famed recourse to "an ideal speaker-hearer $|\ldots|$ unaffected by $|. .$.$| grammatically irrelevamt conditions" (1965: 3), i.e. hy social life.$ Nobody can blame Chombly for hiding out his principle however: not once has he moved from his early Russellian views of what "science" is

I can only repeat that the key is in the vance (or posture) of the scholar. The same system will be used by some in a closed sense, while others will attempt to keep it alive, ite. fircus on its implementation by reallife participants. That some exponents of the PS mexdel write in al very abstract mode of course predisposes the more order-prone (or order-averse) among us to overlesh its potential opennews. I myself am recurrently guilty of misjudgeme'nt in this regard

8. Chambon and Simeoni, forthcoming.

9. This kind of statement must sound terribly glib to the non specialist. I can only refer here, for lack of space. 10 a paper I read at the CATS meeting in Calgary in 1994, in which I attempled to show, strictly on a genealogical basss, that as the branch of theoretical linguistics developed in the US and became 'mainstream, its supporters excluded from their concerm any notion of a contextualized linguistics. As the need for such work could not be dismissed however, it thrived in the margins, giving birth periodically to newer schools acting like so many "returm of the repressed": seciolinguistics, pragmatics, discourse analysis, etce. This permatnem epistemological coup was "disciplinarily" successful, hut it had a number of unfornunate consequences, among which the hlanket rejection of linguistic theory by other language specialists, including translators and most translation scholars.

10. Recill that the medal habitus is not interioried by all. It serves only as the reference medel. Many agents strive to distinguish themselves from this model. When dissenters find themselves in institutions that have perfectly assimilated the molal hahitus, they feel misundersteod, hecome embittered. Bourdieu has recently

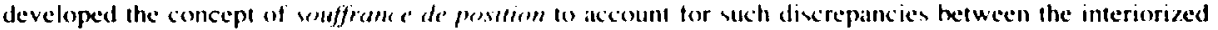
habitus of the agent and his/her actual, objective presision in the field.

11. Whether mainstream psychology will one day return (o) the study of the individual psyche from an "["-perspective, thus joining the ranks of the human sciences is, given the historical configuration of the field. far from certain.

12. The differentiation upon which I am founding this analysis is valid for the anglophone/francophone complex of events and, I believe with special adjustments, for the Western World, roughly speaking the linguistic domain of which is what Benjamin lee Whorf called SAE, "Standard Average European" (1956: 38). I have no doubt that equally legitimate cognitive modes of doing science exist slsewhere, of which one casy point of entry would he at comparative antlysin of the relevant lexical semantic fields of the culture-specific term-equivalents for "science," "knowledge." "episteme." etc.. in momolingual dictionaries.

13. The standard practice consists in conducting experiments hased on 'representative' samples, controlling a few token varriables (usually gender, age, professional training. eft.). 10 find out correlations between the sample and at hypothesied output. As it is increasingly difficult to ignore the criticisms levelled at the representativeness of such constructs, it is common to read dixclaimers os the effect that: 'the sample cannot be considered representative, or 'the evidence is inconclusive.' For all the claims that experiments should he set up in ways that allow for replication. the fact is that few altempts are made at replicating the conditions of the experiment for validation. When this happens, it is net uncommon for the inital results to be disproved. But even when results converge, it often takes an act of faith to be-lieve that the representativeness of the first sample equates that of the new subjects. How could all humban variables be controlled?

14. See Heilbron (1995), in particular chapter $5, \mathrm{pp}$. $94-1(16$, for an overview of the Scottish rexts of Anglosaxon positivist empiricism as distinct from the socio-genesis of the vocial sciences in France.

15. In the US at least (with (anadian agencies following close behind). the order of the day is that of the NIMH. The right-shift ++ of human-science rhetoric has been accompanied by a debunking of major scientific figures formerly identifiable with the right-side mainstream, now removed to an order of scientificity considered humanstis in a derogatory sense. One in reminded of Wilfred Tronter's hard-nomed scientism vis-di-vis Freud's works: "However much one may he impressed by the greatness of the edifice which Freud has huilt up and by the soundness of his architeclure, one can scarcely fail. on coming into it from the hracing atmosphere of the hiokngical sciences, to be oppressed hy the colour of humnatly with which it 
is pervaded" (quoted by Bettelheim. op.cit.. p. 49). This epistemological shift of ideological center accounts for the virulence of some of the attacks waged against Freud and non-strict NSModelling in general.

\section{REFERENCES}

AUSTIN, J. L. (1962): Sense and Sensibilia. London, Oxford University Press.

BAR-HILLEL. Yehoshua (1960): "A Demonstration of the Nonfeasibility of Fully Automatic High Quality Translation". Appendix III to: "The Present Status of Automatic Translation of I anguages". in: F. L. Alt (Ed.). Adiances in (omputers, vol. I. New York. Academic Press, pp. 158-16.3. Reprinted in Langucuge and Information. Selected Essays on their Theory and Application, by Yehoshua Bar-Hillel. Reading (Mass.). Palo Alio and London. Addison-Wesley Publishing Company, pp. 174-179.

BETTEL.HEIM. Bruno (1982): "Reflections. Freud and the Soul", in The Nen Yerker. March 1 issue, pp. 52-9.3. Published in book form in 1984 as: Freud and Man's Soul. New York. Vintage Bonks.

BOURDIEU, Pierre (1977): "La production de la croyance: contributions a une economie des biens symboliques", in Artes de la recherche e'n sciences sociales, 13, pp. 3-4.3, English translation hy Richard Nice as: "The Production of Belief: Contribution to an Economy of Symbolic Coxxls", in P'. Bourdieu: The Field of (ultural Production Essays on Art and Literature. Randal Johnson (Ed.). New York. Columbia University Press, pp. 74-111.

BOURDIEL", Pierte (1984): "Réponses aux economistes", Economies ef sociétés, XVIII-10, pp. 23-32.

BOURDIEU, Pierre (1989): La noblesse d' État. Grandes écoles ef esprits de corps. Paris. Minuit.

BOURDIEU, Pierte ( 1990 ): "The Scholastic Point of View". translated by L. Wacquant. Cultural Anthropology, 5-4. Pp. 380-391.

BOURDIEU, Pierre (1991): Cours du Collège de France. See also: (1993): Esprits d' Eiat. (ienèse te struchure du champ bureau ratique. Actes de la recherche en sciences sociales, 96/97, pp. 49-62.

BOURDIEU, Pierte (1994): Raisons Pratiques. Sur la Théorie de l Action. Paris, Le Seuil.

BRIJNFR. Jerome S. (1990): A ( os of Meaning. Cambridge (Mass.) and London. Harvard University Press.

CATFORD. J. C. (1965): A Linkustic Theory of Trans/ation. An Essay in Appliod Lansuistics. London. Oxford University Press.

CHAMBON. Adrienne and Daniel SIMEONI (Fonhcoming): La modalisation dans le dialogue thérapeutique.

CHAZEL. François ( 149,3$)$ : "l:esthétisme sceptique et ses limites en histoire de la sociologie", Revue françarse de sriviologic. 34-2. pp. 247-269.

CHOMSKY. Noam (1965): Aspects of the Theory of Syntax, Cambridge (Mass.). The MIT Press.

DUBET, François (1994): "Vraisemblance: entre les sociologues el les acteurs". L'Anné sociologique,. 44, pp. $83-107$.

El.IAS. Norbert (1956): "Problems of Involvement and Detachment", Brifish Journal of Siciology, 7, pp. 226-252.

EL.JAS. Nortert (1994): Refleciouns on a Life, translated by Edmund Jephcolt, Cambridge (UK), Polity Press.

FRECCER(), John (1988): "Foreword", in A.K. Forcione. H. Lindenberger and M. Sutherland (Eds.). Lees Spitzer. Representative Essays. Stanford. Stanford University Press, pp. xi-xx.

FRIFDRICH. P. (1995): Revien', Anna Wierzbicka: Semantics. Cullure and Cogmrion: Unicersal Human Cancepts in Culture-specific Configurations, Oxford and New York. Oxford University Press, Language in Sociery, 24, pp. 111-113.

GEERTY. Clifford (1988): Works and Lives. The Amthropologisf as Author. Stanford. Stanford (Iniversity Press.

GADDIS-ROSE, Marilyn (1994): "In the Theory Spectrum. Fragmentation is a Sign of Life", Oral communication. 7th Annuat Conference of the Canadian Association of Translation Studies. Iniversity of Calgary. To be published in $T T R$.

GILE. Daniel (1995): "La lecture critique en traductologie", Meta, XL-1, pp. 5-14.

GORTZ. Andre (1989) (1958): The Traisor, London, Verso.

GOULD. Stephen J. (1981): The Mismeasure of Man. New York and London, W.W. Nonton \& Company.

HEILBRON. Johan ( 1991 ): "Pionniers par défaut? Les débuts de la recherche au Centre d'études soxiologiques (1946-1460)", Revue fransaise de sociologie, XXXII, pp. 365-379.

HEILBRON. Johan (1995): "The Rise of Social Theory", translated by Sheila Gogol, ("onmodictions of Modernity, vol. I. Minneapolis. University of Minnesota Press.

HEARNSHAW, L. S. (1979): Cyril Burt prychologist, London. Hodder and Stoughton.

HOULE, Gilles (In press): "Common Sense as a Specific Form of Knowledge: Elements for a Theory of Otherness". translated by Jan Marontate, in D. Simeoni and M. Diani (Eds.), Biographical Researih. Current Sociology, vol. 43-2.

KNORR-CETINA, Karen (1995): "Theoretical Constructionism: Machines of Knowledge and the Archaeology of Social Domains". Oral communication. Annual Conference of the Graduate Program in Literature: Pierre Bourdieu: Fieldn'ork in Cullure. Duke University. North Carolina.

LABOV. William (1987): "The Overestimation of Functionalism", in Rene Dirven and Vilem Fried (Eds.), Functionalism in Linguistics. Amsterdam/Philadelphia. John Benjamins Publishers, pp. 311-3.32. 
LANGACKER, Ronald W. (1987): Foundations of Cognitive Grammar, Stanford, Stanford University Press. LEPENIES, Wolf (1985): Die drei Kulturen. Soziologie zwischen Literatur und Wissenschaft, München, Hanser. LINELL. Per (1982): The Written Language Bias in Linguistics. Linkoping. Department of Communication Studies. Studies in Communication.

LYONS, John (1984): "La subjectivité dans le langage et dans les langues", in G. Serbal (Ed.), Émile Benveniste aujourd' hui. Actes du Colloque International du CNRS, Paris, CNRS, pp. 131-139.

MARCUS, Laura (In press): "Autobiography and the Politics of Identity", in D. Simeoni and M. Diani (Eds.). Biographical Researsh, Current Sociology, vol. 4.3-2.

MAYNARD. Senko K. (1993): Discourse Modality. Suhjectivity, Emotion and Voice in the Japanese Language, Amsterdam/ Philadelphia. John Benjamins Publishing Company.

MILLER, Arthur I. (1986): Imagery in Scientific Thought. Cambridge (Mass.) and London (UK), The MIT Press.

MOSSOP, Brian (1995): "Translating as Reporting/Quoting: A Theoretical Characterization of the Translator", Oral communication, 8th Annual Conference of the Canadian Asscxiation of Translation Studies, UQAM. Montreal.

MOUNIN. Georges (1963): Les problemes théoriques de la traduction. Paris. Gallimard.

NIDA, Eugene (1946): Morphology: The Descriptive Analysis of Words. Ann Arbor. The University of Michigan Press.

NIDA, Eugene (1964): Towards a Science of Translating. With special reference to principles and procedures invelved in Bible translating, Leiden. E. J. Brill.

NIDA. Eugene (1975): Compomential Analysis of Meaning. An introduction to semantic structures, The Hague and Paris. Mouton.

QIAN HU (1992-1994): "On the Implausibility of Equivalenı Response", parts 1-5, Meta, XXXVII-2. pp. 289 3(0): XXXVII-3. pp. 491-506; XXXVIII-2, pp. 226-237; XXXVIII-3, pp. 449-467; XXXIX-3, pp. 4I8-432.

RAMMSTEDT, Angela (In press): "Biographical Research in Italy", in D. Simeoni and M. Diani (Eds.) Biographeral Researsh. Current Sociologv. vol. 43, 2

ROBYNS, Clem (1992): "Towards a Socio-semiotics of Translation". Romanissiscthe Zeitschrift für Literaturgeschichte/ Cahiers d Histoire des Litteratures Romanes, special issue 1/2, pp. 211-226.

SCOLLON. Ron (1995): "Plagiarism and ideology: Identity in intercultural discourse", Languaxe in Societv, 24. pp. 1 .28.

SIMEONI. Daniel (1988) "Language Processes and the Metalinguistic Puzsle". in M. Diani (Ed.). Designing the Imimaterial Sociefy, Design Issues, IV, 1\&2. pp. 116-130.

SIMEONI, Daniel (1992): "Comment traduire la pensée d'État?" Oral communication: 5th Annual Conference of the Canadian Association of Translation Studies. University of P.E.I., Charlottetown.

SIMEONI, Daniel (199.3a): "L'institution dans la langue: lexique et pensée d'État", TTR, VI-1, pp. 171-202

SIMEONI, Daniel (199.3b): "Traduire la recherche". Oral communication, 6th Annual Conference of the Canadian Asscxiation of Translation Studies, Carleton University, Ottawa.

SIME(ONI, Daniel (1994): "La traductotogie au confluent thécrique des sciences humaines et sociales". Oral communication. 7th Annual Conference of the Canadian Association of Translation Studies. University of Calgary.

SIMEONI, Daniel (1995): "Bourdieu across Borders", Oral communication, Annual Conference of the Graduate Program in Literature: Pierre Bourdieu: Fieldwork in Culture, Duke University, North Carolina.

SIMEONI, Daniel and Khadiyatoulah FALL (1992): "Syntagmatic Dysfluency and Discourse Appropriation: Topic Hare and Notional Tug-of-War in Interactional Spoken Language", RS/S/, 12-3, pp. 87-117.

SPIT/ER, Leo (1988) (1948): "Linguistics and Literary History". in A.K. Forcione, H. Lindenberger and M. Sutherland (Eds.). Leo Sprtzer: Representative Essaws. Stanford. Stanford University Press, pp. 3-39.

WEBER, Max (1946) (1915): "Religious Rejections of the World and Their Directions", translated by H. H. Gerth and C. Wright Mills, in From Max Weher: Essays in Sociology. New York. Oxford University Press, pp. 32.3-3.59.

WHORF, Benjamin L. (1956) (19.39): "The Relation of Habitual Thought and Behavior to Language". in Lamguager. Thought and Realiry. Selected Writings of Benjamin lee Whorf. Joint publishers: The Technology Press of Masachusetts Institute of Technology and John Wiley \& Sons. Inc.. New York, and Chapman \& Hall, L.td. London, pp. 1.34-1.59. 